\title{
Variability Assessment of Okra (Abelmoschus esculentus (L.) Moench) Genotypes Based on Their Qualitative Traits
}

\author{
Nesru Temam (iD, ${ }^{1}$ Wassu Mohammed, ${ }^{2}$ and Shimelis Aklilu ${ }^{3}$ \\ ${ }^{1}$ Crop and Horticulture Directorate, Ethiopian Biodiversity Institute, Addis Ababa, Ethiopia \\ ${ }^{2}$ School of Plant Science, Haramaya University, Haramaya, Ethiopia \\ ${ }^{3}$ Melkassa Agricultural Research Center of Ethiopian Institute of Agricultural Research, Addis Ababa, Ethiopia \\ Correspondence should be addressed to Nesru Temam; nesrutemam25@gmail.com
}

Received 2 November 2020; Revised 15 December 2020; Accepted 2 January 2021; Published 15 January 2021

Academic Editor: Isabel Marques

Copyright (c) 2021 Nesru Temam et al. This is an open access article distributed under the Creative Commons Attribution License, which permits unrestricted use, distribution, and reproduction in any medium, provided the original work is properly cited.

The present study was conducted on okra (Abelmoschus esculentus (L.) Moench) genotypes collected from Benishangul Regional State of Western Ethiopia. The objective of this study was to assess the genetic diversity of okra within a regional state based on qualitative traits at Melkassa Research Center during the rainy season of 2019. The results showed that the okra genotypes collected from the regional state had a wide variation in growth habits, leaf, fruit, flower, and seed in their qualitative traits, namely, shape, color, and other quality factors like pubescence which is a determinant factor in consumer preference. Therefore, the result of this study is an indicator for the presence of a higher chance to develop okra varieties highly preferred by domestic and foreign markets through selection/crossing of okra genotype collected from Benishangul Gumuz regional state; as an example, accession 29622 had a smooth texture of fruit with green fruit color which is preferable by consumers. However, the genotypes showed greater variability for plant branching habits that has its effect mainly related to contamination of branches and fruits by soilborne microorganisms and the soil itself during irrigating fields. Finally, it is better if molecular characterization is to be followed by the current morphological characterization and evaluation work.

\section{Introduction}

Okra (Abelmoschus esculentus (L.) Moench) belongs to the family Malvaceae and it is a very important vegetable crop grown in tropical and subtropical parts of the world [1]. Okra is proposed to be originated in Tropical Africa and it is native to North Eastern Africa in the area of Ethiopia and Sudan from where it extensively spread to Asia, America, Southern Europe, and other countries [2,3]. It is self-pollinated, mainly propagated by seeds with a duration of 3 to 4 months $[4,5]$.

It has a considerable area under cultivation in Africa and Asia in particular because of its contribution to the human diet by supplying fats, proteins, carbohydrates, minerals, and vitamins. Its mucilage is suitable for medicinal and various industrial applications [6-9]. The unripe green finger-like seed capsule of okra, usually called "pod," is processed and consumed as stews and salads, soups, sliced, boiled, and fried vegetables $[10,11]$. The fruits contain effortlessly digestible fiber, fat-free contents, and low calories [12, 13]. Okra typically differs from most other common vegetables in having high mucilage content [14]. The seed is used as a coffee additive or substitute [15].

Okra is a traditional crop in southwestern, western, and northwestern Ethiopia [16]. The crop is cultivated from landraces over the years in the country [17]. Recently in 2016, the first improved variety (Bamia Humera) has been recommended for cultivation [18]. However, currently, the few studies conducted indicated that the country is rich for the diversity of the crop $[16,17,19-23]$ based on quantitative traits which is a good opportunity to improve the crop through characterization and evaluation of the available germplasm in the country. Geographic distances and environmental differences are the two major causes of genetic diversity among plant populations [24, 25]. Evolutionary forces like selection, mutation, migration, and genetic drift 
are the basis of crop genetic diversity [26]. There may be also differences in data registration because descriptors tend to be highly subjective [27].

The collection of desirable plant germplasm relies on the proven accession features and genetic divergence, which are essential in genetic resource utilization [28-30]. In this regard, morphological characterization involves both the quantitative and qualitative traits' performance of plants under study. Progress and gain from the selection in any breeding program depend upon the magnitude of useful variability present in the population and the degree to which the desired traits are heritable. The morphological variation observed in these studies is indicative of differences in the genetic makeup of germplasm. Although few of these studies reported that some of the traits are highly heritable and could be used in the selection process during improvement programs, further studies are required to exploit our genetic resources. Yield increment only is not enough in crop improvement unless the quality of produce is considered [17]. Therefore, it is mandatory to consider qualitative traits like shape, color, texture, and others during the study. The okra genotypes collected from different regions and countries may be distributed into varied categories of plant habit, stem color, and plant alignment, and the proportion of genotypes in each category may vary due to either inherent characteristic differences and environmental differences where the genotypes grow or selection of different genotypes by a human being.

In Ethiopia, despite a wide variability recorded for pod yield among the genotypes of different geographic locations, the qualitative traits of genotypes are not studied as well. Moreover, among current experimental materials, 24 genotypes are new collections. Therefore, it is imperative to study the variability among the collected accessions. Hence, the objective of the study was to assess the degree of variability and their qualitative characters among the okra collection with the ultimate goal of providing input for okra variety improvement and its conservation in the country.

\section{Materials and Methods}

2.1. Description of Study Area. The study was conducted at Melkassa Agriculture Research Center (MARC), Ethiopia, in the 2019 main rainy season. Malkasa is located at $8^{0} 24^{\prime} \mathrm{N}$ latitude and $39^{\circ} 21^{\prime} \mathrm{E}$ by having a distance of around $112 \mathrm{KM}$ from Addis Abeba in the Eastern direction at an altitude of 1550 m.a.s.l. The area is characterized by low and erratic rainfall with a mean annual rainfall of $763 \mathrm{~mm}$ with peaks in July and August. The dominant soil type of the center is andosol of volcanic origin with $\mathrm{pH}$ that ranges from 7 to 8.2 . The mean annual temperature is $21.2^{\circ} \mathrm{C}$ with a minimum of $14^{\circ} \mathrm{C}$ and a maximum of $28.4^{0} \mathrm{C}$ [31] (http://www.eiar.gov.et/marc).

2.2. Experimental Materials and Design. A total of 36 genotypes were evaluated, of which 33 okra genotypes were collected from different areas of Benishangul Gumuz Regional State of Ethiopian by the Ethiopian Biodiversity Institute and two of the varieties were introduced from India and now registered as a commercial variety in Ethiopia by one company and one variety is released from Humera research center. The okra genotypes were collected at different altitudes ranging from 661 to $1518 \mathrm{~m}$.a.s.l. The three registered varieties will be used as the standard checks. Genotypes were evaluated on the field in $6 \times 6$ simple lattice designs. Each plot had $0.8 \mathrm{~m} \times 5.4 \mathrm{~m}\left(4.32 \mathrm{~m}^{2}\right)$ consisting of one row and a total of 12 plants per row or plot. The spacing between plant, plots, and adjacent replications was $0.45,0.8$, and $2 \mathrm{~m}$, respectively. Three seeds were sown and thinned to one plant per hill when plants reached the $4-5$ leaves stage.

2.3. Data Collections. International Plant Genetic Resources Institute's [32] descriptor list and published documents for okra species were used to record data on qualitative traits. Qualitative traits were recorded per row basis, and five randomly selected tender fruits from each harvest in each plot were used to record tender fruit-related traits.

2.3.1. Plant Habit and Stem Related Traits. Plant habit and stem color were measured on a row basis properly.

2.3.2. Leaf- and Flower-Related Traits. Leaf color, leaf petiole color, leaf pubescence, and leaf shape were recorded during the booting stage whereas flower color was recorded during flower opening.

2.3.3. Fruit-Related Trait and Seed Shape of Okra. Immature fruit color and position of fruit on the main stem were recorded on the field whereas fruit pubescence, nature of fruit base, the shape of a fruit, and shape of seed were also at the laboratory.

2.4. Data Analysis. Shannon Waver Diversity Index is a commonly used diversity index that takes into account both the abundance and evenness of species or a character present in the community. It is explained by the following formula:

$$
H^{\prime}=-\sum\left(\frac{\mathrm{Ni}}{N}\right) * \operatorname{In}\left(\frac{\mathrm{Ni}}{N}\right)
$$

where $H^{\prime}$ is the Shannon-Weaver Diversity Index expressed as $e^{H^{\prime}}$ and $N$ is the number of observation/descriptor states in the $i^{\text {th }}$ descriptors divided by the total number of characterized plants.

\section{Results and Discussion}

\subsection{Qualitative Traits of Okra Genotypes}

3.1.1. Plant Habit and Stem-Related Traits. A total of 18 (50\%), $14(38.89 \%)$, and $4(11.11 \%)$ genotypes had a plant habit of the densely branched base, densely branched all over, and densely branched at the apex, respectively. All genotypes under study showed erect growth habits, and a large proportion of $26(72.22 \%)$ okra genotypes had green with a red patch stem color while 7 (19.44\%) and $3(8.33 \%)$ genotypes had red or purple and green stem colors, respectively (Figure 1). This indicated that the okra genotypes 


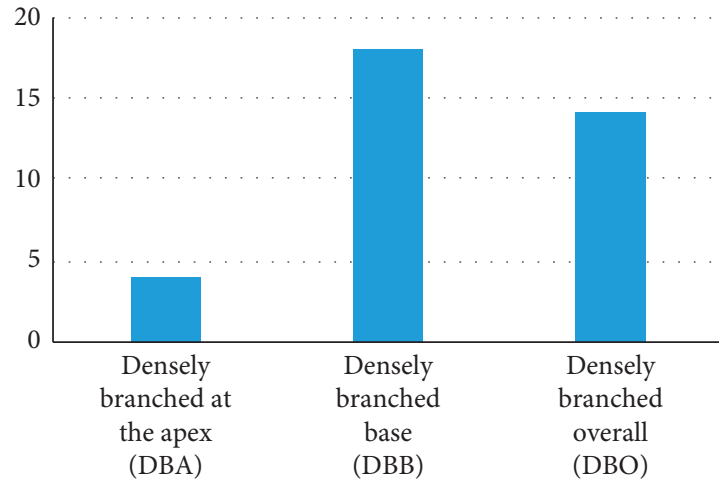

(a)

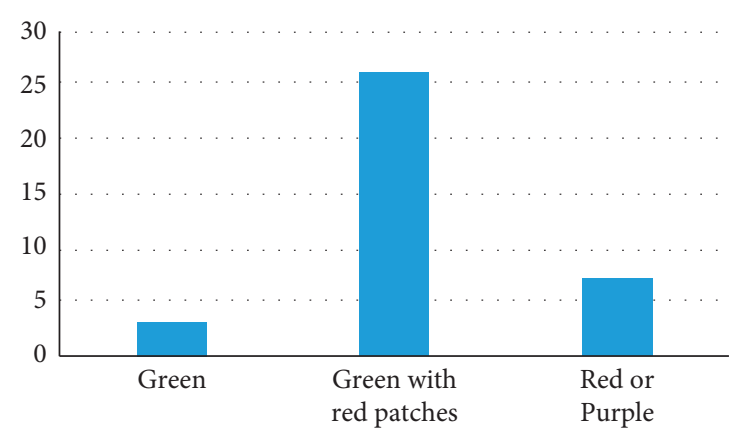

(b)

FIgURE 1: The number of okra genotypes as distributed into categories of plant habit (a) and stem color (b) evaluated at [31].

were distributed into three categories of each trait though 50 to $72.22 \%$ genotypes were grouped in one of the categories of each trait. The okra genotypes collected from different regions and countries may be distributed into varied categories of plant habit, stem color, and plant alignment, and the proportion of genotypes in each category may vary due to either inherent characteristic differences and environmental differences where the genotypes are grown or selection of genotype differences by a human being. Evolutionary forces like selection, mutation, migration, and genetic drift are the basis of crop genetic diversity [26]. There may be also differences in data registration because descriptors tend to be highly subjective [27].

Tripath et al. [33] reported that the stem of the okra plant is robust, erect, and variable in branching and varies from 0.5 to 4.0 meters in height, and the stem is pigmented with green or reddish tinged color. Muluken et al. [21] reported that densely branched base (DBB) characters were $92 \%$ in frequency, were densely branched overall, and had nonbranched growth habit of $4 \%$ for each. Besides other authors, Oppong-sekyere et al. [34], Tesfa and Yosef [17], and Wassu et al. [22] reported that the growth habit and degree of branching of okra germplasm are highly variable. About 59\% of accessions are erect type while $24.7 \%$ and $16.4 \%$ of accession are characterized by medium growth and procumbent type of growth alignment, respectively. The stem of okra was 32, 24, and $44 \%$, showing green, green with red patches, and red/purple color, respectively. Also, they reported that most okra genotypes are densely branched at base characters followed by densely branched overall and branched at the apex.

3.1.2. Leaf- and Flower-Related Traits of Okra. The tested genotypes had great variations for leaf-related qualitative traits, namely, leaf color, leaf petiole color, leaf pubescence, and shape of a leaf (Figure 2). Out of 36 genotypes, $22(61.11 \%)$ and $14(38.89 \%)$ genotypes showed green with red veins and green leaf color, respectively. The leaf petiole of 36 genotypes was observed as red above but green below $27(75 \%)$ and red on both sides $9(25 \%)$ among evaluated genotypes. The leaf pubescence traits observed among 36 genotypes were as follows: 31 (86.11\%) had slight leaf pubescence, $3(8.33 \%)$ had glabrous leaf pubescence, and $2(5.56 \%)$ had conspicuous leaf pubescence. The study also revealed five distinct leaf shapes: 11 (30.56) were heart-shaped, 10 (27.78\%) were broadly ovate, $10(27.78 \%)$ were palmately lobed with a serrated margin, $3(8.33 \%)$ were star-shaped, and 2 $(5.56 \%)$ were with palmately triangular lobes. Similar results were reported by Wassu et al. [22] stating that among 25 okra genotypes, 60\% showed green with red vein and $40 \%$ had green leaf colors. Tesfa and Yosef [17] reported three distinct leaf colors, namely, green with red veins $(26.5 \%)$, green color (60.3\%), and red color $(13.2 \%)$. Besides, they also reported that $67.1 \%$ had slight leaf pubescence, $19.2 \%$ had glabrous leaf pubescence, and $13.7 \%$ had conspicuous leaf pubescence among 50 tested genotypes. Muluken et al. [21] reported that genotypes show that $48 \%$ were heart-shaped, $28 \%$ were broadly ovate-shaped, $16 \%$ were star-shaped, and $8 \%$ were palmately lobed with a serrated margin of leaf shape.

All okra genotypes show flower color with red color on both sides except one genotype which shows red color inside only. A similar result was reported by Muluken et al. [21] where all okra genotypes showed uniform red flower color at both sides. Wassu et al. [22] also reported that 22 (88\%) and three $(12 \%)$ okra genotypes had flowers with red color at both sides and red color inside only, respectively.

3.1.3. Fruit-Related Trait and Seed Shape of Okra Genotypes. The current research reveals the presence of variation among tested genotypes for immature fruit color, the position of fruit on the main stem, fruit shape, fruit pubescence, and nature of fruit base (Figure 3 ). The immature fruit color of $20(55.56 \%)$ genotypes was green with a red patch, $15(41.67 \%)$ had green color, and 1 $(2.78 \%)$ had yellow-green color. All genotypes had slight fruit pubescence except one genotype which had an irritating character at harvest unless we used gloves during harvest. In addition to this, 25 (69.44\%), 10 (27.78\%), and $1(2.78 \%)$ genotypes show erect, intermediate, and 


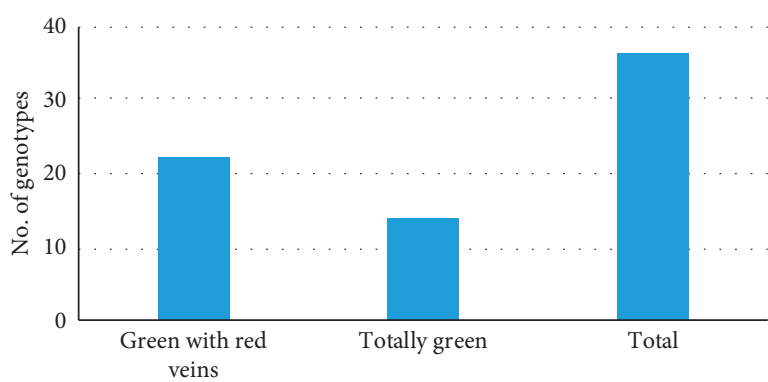

(a)

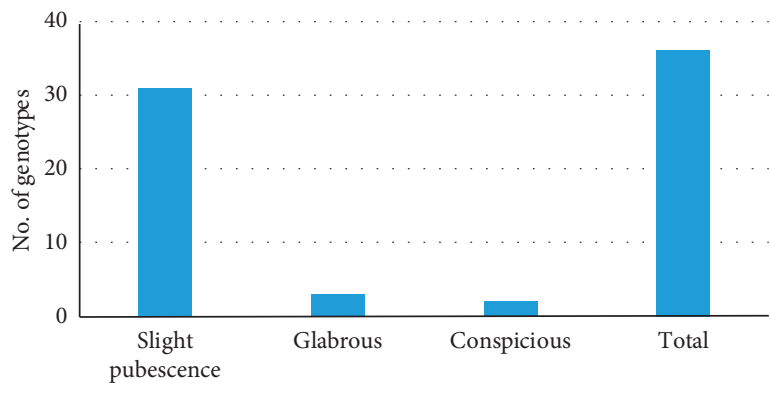

(c)

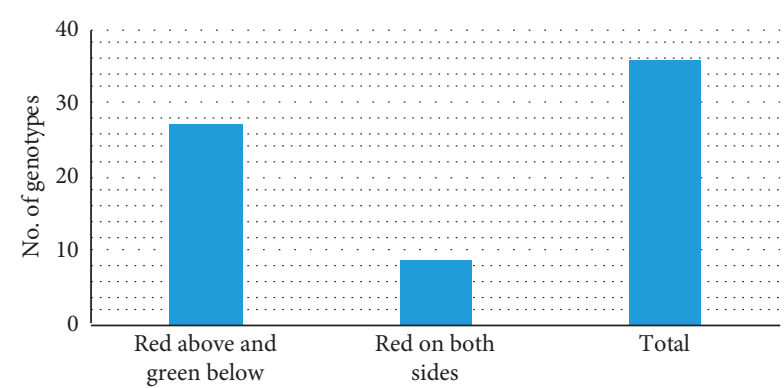

(b)

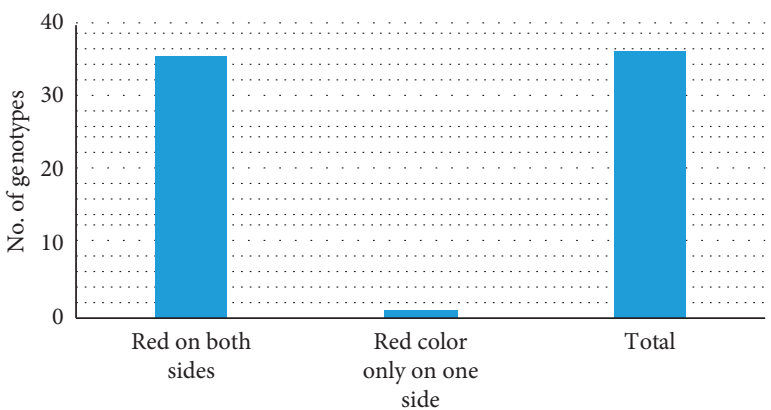

(d)

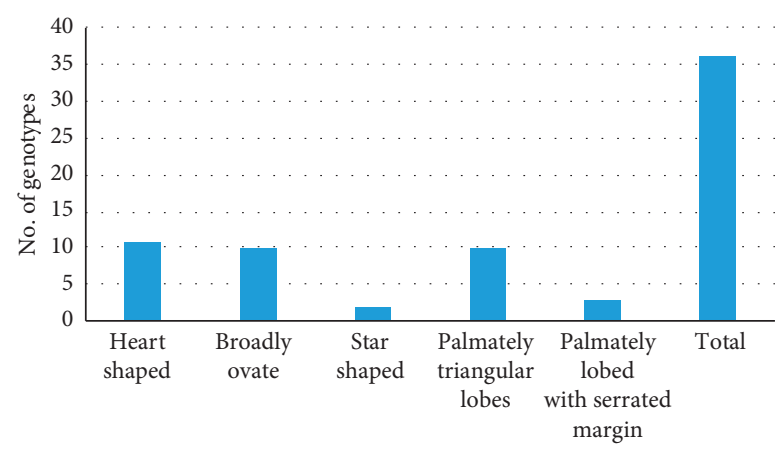

(e)

Figure 2: The number of okra genotypes as distributed into categories of leaf color (a), leaf petiole color (b), leaf pubescence (c), flower color (d), and shape of a leaf (e) evaluated at [31].

horizontal fruit positions on the main stem, respectively. The genotypes had three different fruit base natures; of which, 25 (69.44\%), $6(16.67 \%)$, and $5(13.89 \%)$ are ringed protrude, ringless (flat), and sunken fruit base, respectively. Fruit shape showed the greatest diversity among the okra accessions: from shape scores 1, 2, 3, and 4 as 41.67, $13.89,16.67$, and $27.78 \%$, respectively, according to fruit shape score (Supplementary Figure 1). This result shows the presence of variation among genotypes studied which may be due to the distribution of genotypes and an environmental difference that indicates the possibility of improving fruit qualitative traits through the selection and/or crossing of genotypes from the regional state.

Muluken et al. [21] observed that $72 \%$ and $28 \%$ of genotypes had green and yellow-green immature fruit color, respectively, and $68 \%$ and $32 \%$ of genotypes had an erect and intermediate position of fruit on the main stem, respectively.
Tesfa and Yosef [17] also reported that 56.1\% had yellowishgreen immature fruit color, $25.8 \%$ were green, $12.1 \%$ were green with red, $3 \%$ were dark green, and $3 \%$ had dark red immature fruit colors. They also identify fruit pubescence as follows: $29.6 \%$ were down, $35.2 \%$ were slightly rough, and $35.2 \%$ were prickly. Adeoluwa and Kehinde [29] reported that $60 \%$ had an erect fruit position and $40 \%$ had a horizontal fruit position on the main stem and $56 \%$ had a smooth fruit pubescence and $44 \%$ had a rough fruit pubescence. They also reported three distinct fruit colors of green (42.85\%), purple (48.57\%), and green-yellow (8.57\%).

The genotypes showed three seed shapes: 4 (11.11\%) had reniform (kidney) shape and 16 (44.44) had round and spherical shapes each. Oppeng et al. [34] reported that among genotypes, 24, 40, and 36\% showed round, spherical (oval), and kidney (reniform) seed shapes, respectively. 


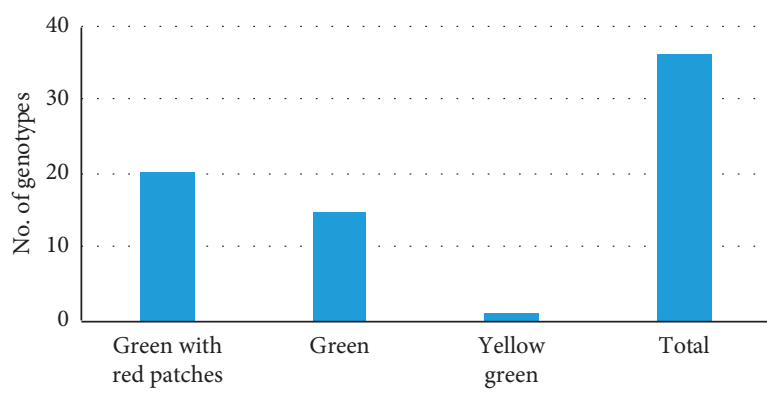

(a)

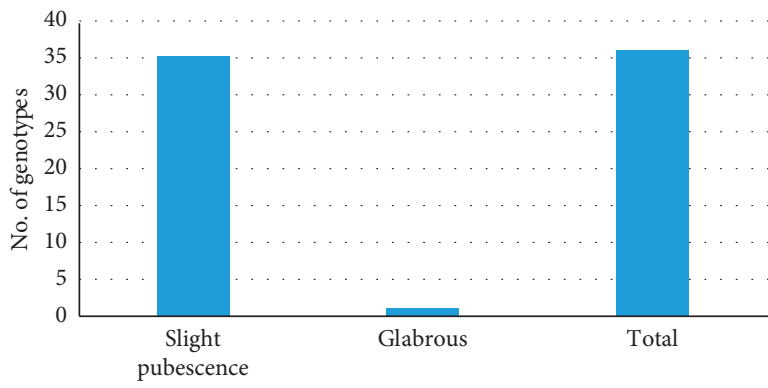

(c)

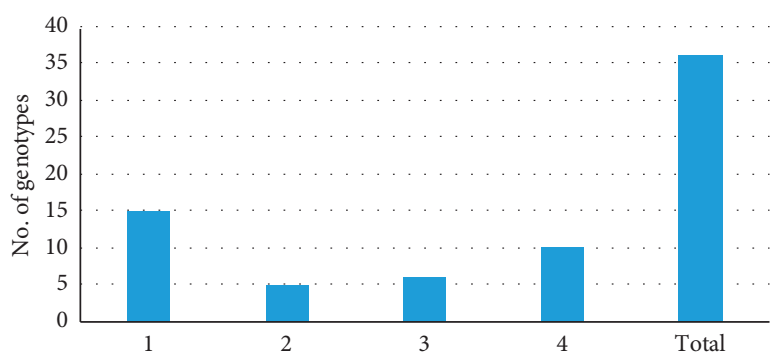

(e)

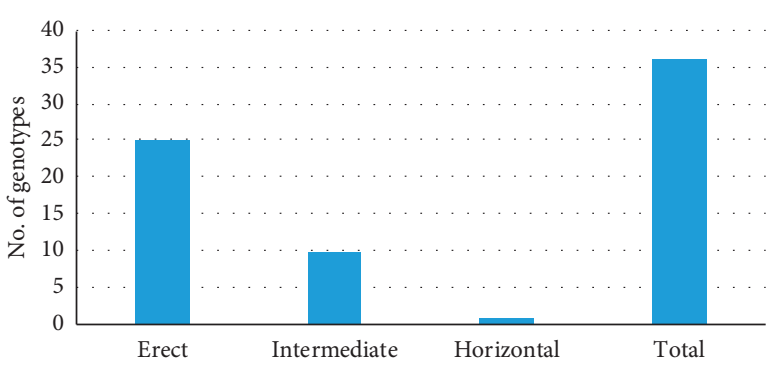

(b)

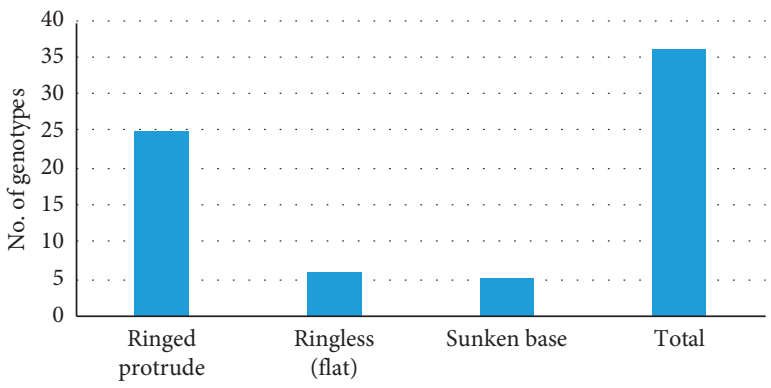

(d)

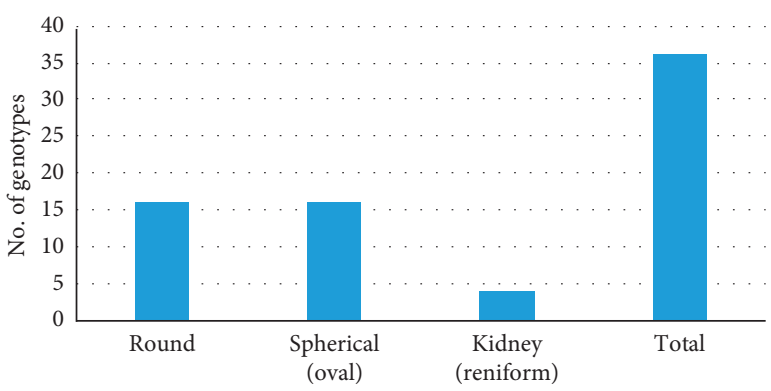

(f)

Figure 3: The number of okra genotypes as distributed into categories of immature fruit color (a), position of fruit on the stem (b), fruit pubescence (c), nature of fruit base (d), fruit shape (e), and shape of seed (f) evaluated at [31].

\section{Conclusion}

The present study concluded that the okra genotypes collected from the regional state had a wide variation for leaf, fruit, flower and seed, shape, color, and other quality factors like pubescence which is a determinant factor in preference of the consumer. Therefore, the result of this study is an indicator for the presence of a higher chance to develop okra varieties highly preferred by domestic and foreign markets through selection/ crossing of okra genotype collected from Benishangul Gumuz regional state; as an example, accession 29622 had a smooth texture of fruit with green fruit color which is preferable by consumers. However, the genotypes showed greater variability for plant branching habits that has its effect mainly related to contamination of branches and fruits by soilborne microorganisms and the soil itself during irrigating fields.

\section{Data Availability}

The raw data are included in the supplementary files, and additional information are available from the corresponding author upon request.

\section{Conflicts of Interest}

The authors declare that they have no conflicts of interest.

\section{Acknowledgments}

The authors appreciate the Ethiopian Biodiversity Institute for financial support and Melkassa Agricultural Research Center for the provision of experiment land.

\section{Supplementary Materials}

Table S1: list and description of okra genotypes. Table 1: the 13 qualitative traits of 36 okra genotypes evaluated at Melkassa in 2019. Table S2: description and score of qualitative traits of okra. Figure S1: fruit shape score [32]. (Supplementary Materials)

\section{References}

[1] D. S. Kisher, K. Arya, K. J. Yogeesh, K. Y. Vinod, and K. HeeJong, "Genotypic variation among okra (Abelmoschus 
esculentus (L.) Moench)," Germplasms in South Indian Plant Breeding and Biotechnology, vol. 4, no. 2, pp. 234-241, 2016.

[2] O. J. Oyelade, B. I. O. Ade-Omowaye, and V. F. Adeomi, "Influence of variety on protein, fat contents and some physical characteristics of okra seeds," Journal of Food Engineering, vol. 57, no. 2, pp. 111-114, 2003.

[3] B. M. Santos, P. J. Dittmar, S. M. Olson, S. E. Webb, and S. Zhang, Okra Production in Florida, pp. 163-171, University of Florida IFAS Extension, Gainesville, FL, USA, 2012.

[4] R. S. Muhammad, A. Muhammad, Z. Khurram, M. J. Muhammad, A. Saeed, and I. Qumer, "Growth, yield and seed production of okra as influenced by different growth regulators," Pakistan Journal of Agricultural Science, vol. 50, no. 3, pp. 387-392, 2013.

[5] M. E. Osawaru, M. C. Ogwu, and J. Omologbe, "Characterization of three Okra [Ablemoschus esculentus (L.)] accessions using morphology and SDS-PAGE for the basis of conservation," Egyptian Academic Journal of Biological Sciences H. Botany, vol. 5, no. 1, pp. 55-65, 2014.

[6] W. J. Lamont, "Okra-A versatile vegetable crop," HortTechnology, vol. 9, no. 2, pp. 179-184, 1999.

[7] FAOSTAT (2004) (http://fao.org).

[8] M. Saifullah and M. G. Rabbani, "Evaluation and characterization of Okra (Abelmoschus esculentus L. Moench.) cultivars," SAARC Journal of Agriculture, vol. 7, no. 1, pp. 92-99, 2009.

[9] S. Haruna, B. S. Aliyu, and A. Bala, "Plant gum exudates (Karau) and mucilages, their biological sources, properties, uses and potential applications: a review," Bayero Journal of Pure and Applied Sciences, vol. 9, no. 2, pp. 159-165, 2016.

[10] W. B. Akanbi, A. O. Togun, J. A. Adediran, and E. A. O. Ilupeju, "Growth, dry matter and fruit yield components of okra under organic and inorganic sources of nutrients," American-eurasian Journal of Sustainable Agriculture, vol. 4, no. 1, pp. 1-13, 2010.

[11] F. O. Daniela, M. Alicia, R. C. Alicia, H. Rodolfo, and Z. V. Sonia, "Quality attributes of okra (Abelmoschus esculentus (L.) Moench) pods as affected by cultivar and fruit size," Journal of Food Research, vol. 1, no. 4, pp. 224-235, 2012.

[12] P. S. Kumar and S. Sreeparvathy, "Studies on heterosis in okra (Abelmoschus esculentus (L.) Moench)," Electronic Journal of Plant Breeding, vol. 1, no. 6, pp. 1431-1433, 2010.

[13] M. T. Reddy, K. H. Babu, M. Ganesh, H. Begum, R. S. K. Reddy, and J. D. Babu, "Exploitation of hybrid vigor for yield and its components in okra [Abelmoschus esculentus (L.) Moench]," American Journal of Agricultural Science and Technology, vol. 1, pp. 1-17, 2013.

[14] V. A. Jideani and B. M. Bello, "Functional properties of okra protein products containing different levels of mucilage," Journal of Food, Agriculture \& Environment, vol. 7, no. 2, pp. 252-255, 2009.

[15] T. Moekchantuk and P. Kumar, Export Okra Production in Thailand, Vol. 56, Food and Agriculture Organization of the United Nations, Bangkok, Thailand, 2004.

[16] M. Yonas, W. Garedew, and A. Debela, "Multivariate analysis among okra (abelmoschus esculentus (L.) Moench) collection in south western Ethiopia," Journal of Plant Sciences, vol. 9, no. 2, pp. 43-50, 2014a.

[17] T. Binalfew and A. Yosef, "Characterization of okra (Abelmoschus esculentus (L.) Moench) germplasms collected from western Ethiopia," International Journal of Research in Agriculture and Forestry, vol. 3, no. 2, pp. 11-17, 2016.

[18] MoANR, Crop Variety Registers Issue No. 19, p. 211, MoANR, Addis Abeba, Ethiopia, 2016.
[19] M. Yonas, W. Garedew, and A. Debela, "Variability and association of quantitative characters among okra (abelmoschus esculentus (L.) Moench) collection in south western Ethiopia," Journal of Biological Sciences, vol. 14, no. 5, pp. 336-342, $2014 b$.

[20] M. Demelie, W. Mohammed, and E. Gebre, "Genetic diversity of Ethiopian okra collections through multivariate analysis at werer, rift valley of Ethiopia," The International Journal Of Science and Technolodge, vol. 3, no. 8, pp. 186-193, 2015.

[21] M. Demelie, W. Mohammed, and E. Gebre, "Variability, heritability and genetic advance in Ethiopian okra [Abelmoschus esculentus (L.) monech] collections for tender fruit yield and other agro-morphological traits,', Journal of Applied Life Sciences International, vol. 4, no. 1, pp. 1-12, 2016.

[22] W. Mohammed, Anteneh Bekele, and V. Kumar, "Characterization and evaluation of okra [Abelmoschus esculentus (L.) Moench] collections in eastern Ethiopia," in Proceedings of 34th Annual review workshop, Haramaya University, Haramaya. Ethopia, April 2017.

[23] N. Temam, "Correlation and path coefficent analysis of pod yield and related traits of okra [abelmoschus esculentus (L.) Moench] genotypes evaluated at Melkassa, centeral Ethiopia," International Journal of Engineering Research and Technology, vol. 9, no. 8, pp. 792-801, 2020.

[24] M. Slatkin, "Gene flow and the geographic structure of natural populations," Science, vol. 236, no. 4803, pp. 787-792, 1987.

[25] P. Nosil, L. J. Harmon, and O. Seehausen, "Ecological explanations for (incomplete) speciation," Trends in Ecology \& Evolution, vol. 24, no. 3, pp. 145-156, 2009.

[26] H. R. Bhandari, A. N. Bhanu, K. Srivastava, and M. N. Singh, "Assessments of genetic diversity in crop plants-An overview," Advance Plant, vol. 76, 2017.

[27] S. Hammon and D. H. Van Stolen, "Characterization and evaluation of okra," The Use of Plant Genetic Resource, vol. 27, pp. 173-174, 1989.

[28] G. Olaoye, O. B. Bello, L. S. Olayiwola, and A. Y. Abubakar, "Analyses of moisture deficit grain yield loss in drought tolerant maize (Zea mays L.) germplasm accessions and its relationship with field performance," African Journal of Biotechnology, vol. 8, no. 14, p. 3229-3238, 2009.

[29] O. AdeOluwa and O. Kehinde, "Genetic variability studies in west african okra (abelmoschus caillei)," Agriculture and Biology Journal of North America, vol. 2, no. 10, pp. 13261335, 2011.

[30] B. O. Bashir and D. Aminu, "Genetic relationships among okra (Abelmoschus esculentus (L.) Moench) cultivars in Nigeria," Acta Agriculturae Slovenica, vol. 109, no. 2, pp. 251-260, 2017.

[31] Melkassa Agricultural Research Center, "Home page datas," 2019, http://www.eiar.gov.et/marc.

[32] IPGRI, "Okra descriptor list," International Crop Network Series 5, International Board for Plant Genetic Resources (IBPGR), Rome, Italy, 1991.

[33] K. K. Tripathi, O. P. Govila, W. Ranjini, and A. Vibha, Biology Of Okra [Abelmoschus Esculentus (L).Moench].Serious Of Crop Specific Biology Document, p. 22, Ministry of Environment and forests government of India and department of biotechnology ministry of science and technology government of India, New Delhi, India, 2011.

[34] D. Oppong-Sekyere, R. Akromah, E. Y. Nyamah, E. Brenya, and S. Yeboah, "Characterization of okra (Abelmoschus spp. L.) germplasm based on morphological characters in Ghana," Journal of Plant Breeding and Crop Science, vol. 3, no. 13, pp. 367-378, 2011. 